\title{
The Views of Lecturers, Students and Administrators on the Impact of Organization in Foreign Language Education to Academic Achievement
}

\author{
Fatma Köprülü ${ }^{1^{*}}$, Behcet Öznacar ${ }^{1}$ \\ ${ }^{1}$ Near East University, Department of Education, Nicosia, N. CYPRUS
}

Received 18 August 2017 • Revised 12 September 2017 • Accepted 11 November 2017

\begin{abstract}
The rapid development of technology from day to day has manifested itself also in the field of education, and therefore it has become compulsory to include new regulations in education. In this fast-paced development, technology is coming into prominence both in distance education and traditional education. In this context, the technological organization established has an important role in the emergence of success perception. Since computer has begun to be used in the field of education, in addition to traditional education, the distance education has become in a more effective and productive education for foreign language learners. In this study, the distance learning, traditional education, teaching environments and perception of organizing as academic achievement are explained. The study has been carried out in a private university in the academic year of 2016-2017. The aim of this study is to evaluate the perception of success between distance education and traditional education in the foreign language education. This study examined the perceptions of administrators, lecturers and students towards the distance learning and traditional learning in order to evaluate the academic success of organizing in foreign language learning. The qualitative data analysis was used in this study. Administrators and students reported that they were prepared to facilitate individual study and improve their work skills with distance learning in the foreign language learning, but that the lecturers were not in the same position with the administrators and students in distance education.
\end{abstract}

Keywords: distance education, traditional education, teaching environments, organization

\section{INTRODUCTION}

Training is essential for people to be trained in the desired qualifications. For this reason, alternatives have recently begun to be explored in ensuring that people receive more qualified education. Many institutions have started the research to ensure that the education provided at higher education institutions can be improved in quality so that the community can move forward as the education affects the society considerably.

This study is based on the evaluation of the impact of organizational success on academic achievement in foreign language learning and the perception of success between distance education and traditional education, pursuant to the views of lecturers and administrators in the North Cyprus. The fact that problems in the traditional education system in universities cannot be resolved while the attractive opportunities offered by the developing technologies have directed the education system to new searches.

Distance education is a type of education that enables teachers and students to communicate at the same time or at different times in different places. Distance education as an educational revolution, enriches traditional faceto-face education and makes it more accessible and affordable (İşman and Dabaj, 2005). 


\section{Contribution of this paper to the literature}

- According to the research results, most of students preferred foreign language learning through distance education due to the lack of a time limit and because of its provision of flexibility in learning.

- Since the layout of organizational units is dispersed in distance learning, the coordination, influence and evaluation diverge from institutions providing face-to-face education and this necessitates a virtual structuring.

- The study concluded that while administrators and students were satisfied with foreign language learning through distance education, the lectures were ending with dissatisfaction in terms of success.

In the present day, the distance education is contemplated as an ideal system of education since it encompasses many features, which are desirable in the system of education. In distance education, the student receives education not passively but rather actively. While the programs in distance education are devised, the interest and skills of the students are always taken into consideration. Individuals are also able to access distance education anytime and anywhere. With distance education, the students find the opportunity to have the same level of education under the same conditions. Thus, distance education brings with it lifelong learning and with the latter individuals assume the responsibility of their own learning processes.

Distance learning is making education available for students in distant areas by electronic means like the computer and multimedia technology (satellite video and audio). Therefore, even if the educator and the student may be in different locations, the function of information flow and education is ensured through technology. Distance education is a method of education beyond the traditional learning-teaching methods, where those planning and implementing educational activities interact with the learners through specifically designed forms of education (Alkan, 2005).

Human beings that live in groups form with others and meet their needs. At the present time, the needs, which become difficult to meet in the face of changing global conditions, necessitate the establishment of an organization. The individuals, who come together to fulfil common goals and meet common needs, form the organization, which is a social structure itself (Şahin, 2004).

An important dimension of distance education is the structure and management of organizations. In order to create an effective management system, a purposive institutional structure must be established. Distance education is divided into dependent and independent institutions. This clustering is shaped by subsystems in distance education (Kaya, 2002).

1. Independent Distance Education Institutions

a. Private and Government Distance Learning Schools or Faculties

b. Distance Learning Universities

2. Mixed Organization Constructions

a. Independent Faculties Offering Distance Learning

b. Consolidation Model

c. Integrated System

The institutionalization of distance education differs significantly from formal education. According to Williams (2000), the roles required to ensure synergy and effectiveness in the institutions of distance education are also differentiated in many aspects: Administrator, facilitator (Educator), technology expert, site facilitator, staff supporter, technician, librarian, assessment expert, trainer, media publisher (editor), graphics designer and leader.

Educational institutions, which see the operation of managerial functions and the management structure as formal, become more complex due to these different roles in the distance education institutions. Managerial functions such as planning, decision-making, communication, organization, assessment, influence and leadership require the inclusion of various units and individuals into the process.

Considering the distance education from the perspective of organization, one can think of formal and informal organizations, who are groups of individuals brought together to accomplish a certain goal. The formal organization represents structural factors such as tasks, hierarchical levels, communication between levels, competences and responsibilities and chain of command.

The informal organization, which is the other aspect of the organization, is defined as the informal and unseen side of the source of individuals within the organization. That is, informal groups represent the natural aspect of an organization like non-business relationships, which are formed automatically. However, both structures should be designed properly for organizational success. 
In order for the organization to fulfill its goals, tasks are designated in different areas and pursuant to the different specialties. These should subsequently be distributed to formal structures like departments, units and groups to be formed within the organization.

The quality of work in the formation of the organizational structure is related with the value created by organization and how this value was created. By virtue of the distance education, the institutions reach large groups of students. While providing this service, students in different regions and locations might benefit respectively. Therefore, the organizational structures of institutions, which provide distance education, are shaped accordingly. When individuals and units are in different locations physically, the required structure in distance education institutions has come to be established virtually. Therefore, a statement like "the optimum organizational structure for such institutions is virtual organization" would be relevant (Gürol and Turhan, 2004).

The virtual organization is a legally apart but functionally independent structure where the employees, administrators and service providers work without being in different locations physically. The employees working in this organizational structure ensure information flow through electronic communication without sharing the same environment. Thus, the cost decreases; a higher degree of efficiency is maintained and the satisfaction level of internal and external customers increases (Weber, 2002).

\section{MATERIALS AND METHOD}

In this research, a qualitative model has been used. Qualitative research is a method, which utilises interviews, document analyses and observations. An effective understanding of perception and attitude is provided by a qualitative research.

This research is based on the views of manager, lecturer and student on the effect of organizing in foreign language teaching in the context of management functions.

\section{Study Group}

The study group of the present research comprises 8 school managers, 12 lecturers and 24 students from Near East University in the Fall semester of the academic year of 2016-2017. The participants were all volunteers.

\section{Data Collection Process}

The research data were collected through one-to-one interviews with the participants in my own office and at times they are available between the dates of 27th December 2016 - 3rd January 2017.

According to Punch (2005), interview is the most effective method, which is used for understanding people's perceptions.

Within the research, face-to-face interviews lasting around 30-40 minutes were made between the researcher and the participants in order to evaluate the perception of success between distance education and traditional education in terms of school managers, lecturers and students in foreign language teaching.

The face-to- face interviews were made in a peaceful conversational environment in order to obtain useful data. All interviews were carried out in English.

\section{Data Collection Tool}

While preparing the interview form for this study, the focus was to ensure that the questions are clear and understandable for the participants. In order to ensure the internal validity, the interview form was delivered to three specialists for examination. The form was finalized after certain questions were taken out of the list since their content were not understandable and clear and after some questions were made more understandable. Finally, interviews were made with 8 administrators, 12 lecturers and 24 students.

The data source of the study consists of written records obtained from interviews with the participants. The participants were contacted beforehand for the time of the interviews, the suitable times and days were arranged and one-to-one interviews were made at a time suitable for both sides. The interviews took around 30-40 minutes. All the views and suggestions articulated during the interviews were written on the form and were thus put on record.

\section{Data Analysis}

Content analysis has been performed as the method of analysis for the interviews. Content analysis is a scanning strategy that focuses on finding the important and meaningful sections of a predefined content. According to Früh 
Table 1. The success of distance education compared to traditional education in foreign language teaching

\begin{tabular}{|c|c|c|c|c|c|c|c|c|c|c|c|c|}
\hline \multirow{3}{*}{ Theme } & \multicolumn{6}{|c|}{$\begin{array}{l}\text { Distance Education } \\
\end{array}$} & \multicolumn{6}{|c|}{ Traditional Education } \\
\hline & \multicolumn{2}{|c|}{ Administrator } & \multicolumn{2}{|c|}{ Lecturer } & \multicolumn{2}{|c|}{ Student } & \multicolumn{2}{|c|}{ Administrator } & \multicolumn{2}{|c|}{ Lecturer } & \multicolumn{2}{|c|}{ Student } \\
\hline & $\mathbf{N}$ & $\%$ & $\mathbf{N}$ & $\%$ & $\mathbf{N}$ & $\%$ & $\mathbf{N}$ & $\%$ & $\mathbf{N}$ & $\%$ & $\mathbf{N}$ & $\%$ \\
\hline Designed programmes & 4 & 50 & - & - & - & - & - & - & - & - & - & - \\
\hline Allows flexibility for learners & 4 & 50 & - & - & 4 & 33 & - & - & 5 & 42 & - & - \\
\hline $\begin{array}{l}\text { Active role in learning and } \\
\text { accessing }\end{array}$ & 2 & 25 & - & - & 5 & 21 & - & - & - & - & - & - \\
\hline No time limit & - & - & 4 & 33 & 9 & 38 & - & - & 8 & 67 & - & - \\
\hline Lack the speaking skill & - & - & 4 & 33 & - & - & - & - & - & - & - & - \\
\hline Opportunity to ask questions & - & - & - & - & - & - & - & - & 3 & 25 & 6 & 25 \\
\hline Better education & - & - & - & - & - & - & - & - & 4 & 33 & 10 & 42 \\
\hline No idea about the success & 2 & 25 & 3 & 25 & - & - & - & - & - & - & - & - \\
\hline $\begin{array}{l}\text { Students focus more in } \\
\text { classroom }\end{array}$ & - & - & - & - & - & - & - & - & 5 & 42 & - & - \\
\hline
\end{tabular}

(2001), the main purpose is to reveal the common aspects of text content. Content analysis is a research technique used to make reproducible and valid inferences by interpreting and encoding textual material.

In this study, qualitative data analysis program NVIVO 11.0 was used for categorization and coding of data. A wide range of content can be easily coded and complex information can be adjusted with NVIVO 11.0 to be more manageable. The program also provides speed recall during encoding and allows the opportunity to analyse the data later. This software greatly alleviates the process of finding common expressions in response to a specific problem. For the validity of the data analysis, the views of the school administrators, lecturers and students where the code and categories were obtained are directly quoted in this study.

\section{RESULTS}

Results obtained in the research were presented by taking as a basis the answers to the aforementioned nine questions. Nine themes were identified to be present for the research. Results related to these themes were tabulated in the form of frequencies and presented in Table 1.

Table 1 Most of the administrators (50\%) participating in the research reported that distance education provided flexibility for students in learning a foreign language and the others $(50 \%)$ stated that the lessons (programs) were better designed. $25 \%$ of them also indicated that it had an active role in learning and access. However, some administrators $(25 \%)$ said that they had no idea about the success of foreign language learning provided by distance education. The lecturers $(67 \%)$ stated that they preferred foreign language teaching through traditional education since there was no time limit, $(42 \%)$, it provided flexibility for students and the students focused more in the classroom, (33\%) it provided better education opportunities for students and also (25\%) provided an opportunity to ask questions to the students. The students $(38 \%)$, on the other hand, stated that they preferred foreign language learning through distance education since there was no time limit, (33\%) provided flexibility to students and (21\%) played an active role in learning and accessing. It can be seen that, both administrators and students reported that they preferred distance education in foreign language teaching.

(A View (8)), "I think that distance education allows flexibility for learners as they can study and attend their lessons whenever or wherever they want. Instructors can design and prepare their programmes according to each individual's level. (Specially-designed programmes)."

(L View (3)), "In my opinion too much exposure to distance learning may not be effective. I think this because students tend to understand and focus more in classroom atmosphere. Students are able to communicate and work collaboratively more, increasing knowledge in schema."

(S View (19)), "My thought about the success of distance education compared to traditional education is that distance education in foreign language teaching has not really been successful seeing that students may get bored during lecture periods as teachers will not be able to display other learning methods skills such as cracking a joke to get the attention of the students in such situations."

Table 2 The administrators (100\%), lecturers (67\%) and students (38\%) who participated in the research argued that the foreign language content provided by distance education is designed to facilitate self-study and improve study skills. The lecturers (33\%) disagreed and the students (63\%) stated that they had no idea about this view. 
Table 2. The foreign language content provided by distance education is designed to facilitate self-study and improve study skills

\begin{tabular}{lcccccc}
\hline \multirow{2}{*}{ Theme } & \multicolumn{4}{c}{ Distance Education } \\
\cline { 2 - 8 } & \multicolumn{2}{c}{ Administrator } & \multicolumn{2}{c}{ Lecturer } & \multicolumn{2}{c}{ Student } \\
\cline { 2 - 8 } & $\mathbf{N}$ & $\%$ & $\mathbf{N}$ & $\%$ & $\mathbf{N}$ & $\%$ \\
\hline No idea & - & - & - & - & 15 & 63 \\
\hline Yes & 8 & 100 & 8 & 67 & 9 & 38 \\
\hline No & - & - & 4 & 33 & - & - \\
\hline
\end{tabular}

Table 3. Evaluating traditional and distance education in terms of speeding up learning

\begin{tabular}{|c|c|c|c|c|c|c|c|c|c|c|c|c|}
\hline \multirow{3}{*}{ Theme } & \multicolumn{6}{|c|}{ Distance Education } & \multicolumn{6}{|c|}{ Traditional Education } \\
\hline & \multicolumn{2}{|c|}{ Administrator } & \multicolumn{2}{|c|}{ Lecturer } & \multicolumn{2}{|c|}{ Student } & \multicolumn{2}{|c|}{ Administrator } & \multicolumn{2}{|c|}{ Lecturer } & \multicolumn{2}{|c|}{ Student } \\
\hline & $\mathbf{N}$ & $\%$ & $\mathbf{N}$ & $\%$ & $\mathbf{N}$ & $\%$ & $\mathbf{N}$ & $\%$ & $\mathbf{N}$ & $\%$ & $\mathbf{N}$ & $\%$ \\
\hline Limited materials & - & - & 5 & 42 & 6 & 25 & - & - & - & - & 7 & 29 \\
\hline Unlimited materials & 4 & 50 & - & - & 20 & 83 & - & - & 8 & 66 & 4 & 17 \\
\hline Time limit & - & - & - & - & - & - & - & - & 5 & 42 & 18 & 75 \\
\hline No time limit & 4 & 50 & 6 & 50 & 15 & 63 & - & - & - & - & - & - \\
\hline Teacher-student relationship & - & - & - & - & - & - & - & - & - & - & 10 & 42 \\
\hline
\end{tabular}

(A View (4)), "Individual work and improving studying skills are in the nature of distance education programs. Because there is no teacher to guide them every minute, the students who are registered to such a program have to find/develop their own learning strategies and become autonomous learners."

(L View (1)), "There are power points which is about the topics, videos which makes you to understand the topics better, there are tests and assignments to track the students' progress. Furthermore, lecturer can assign individual assignments according to students' special needs. For instance, if a student needs more help on reading skills, the lecturer can assign different texts to the student and also s/he can see the students' progress."

(S View (15)), "I agree that the foreign language content by distance education is designed to facilitate self-study and improve work skills since it helps students to discuss their ideas and it also improve socialization."

Table 3 According to the result of another research, both the administrators and the students reported that distance learning accelerated learning in many ways, but that the lecturers did not share the same opinion.

(A View (7)), "Distance education can help to speed up the learning process of the student by allowing them to take as many subjects/classes as they wish in any period of time. It also allows instructors to share more materials with learners whenever they feel it is necessary for each individual."

(L View (1)), "In traditional education there is a time limit but there are unlimited materials that can be used to teach. You can use different texts, videos, pictures, flashcards etc. on the other side, in distance learning there isn't any time limit but materials might be limited. Learners can use only the materials the lecturer uploaded to the system."

(S View (11)), "Traditional education would have a lesser time frame in learning because there would be a teacher-student kind of relationship which would facilitate a quicker understanding and speed up learning. Distance learning education has a higher time frame in learning because there wouldn't be a teacher-student kind of relationship and the student would have to invest much time in understanding by himself alone."

Table 4 shows that, when evaluating the success of students in traditional education, $50 \%$ of the administrators mentioned that the students must study regularly, $25 \%$ of them said that they could have some ideas about the progress of the students and the other $25 \%$ reported that they could have the opportunity for face-to-face interviews. Of the lecturers, 33\% reported that it evaluated all the skills, 33\% said that it gave some ideas about the progress of the students, $25 \%$ mentioned that it gave them the opportunity for face-to-face interviews and $33 \%$ argued that it helped the lecturer shape the lesson according to the objective. $58 \%$ of the students on the other hand, expressed that, the students' performance could be easily evaluated, $25 \%$ of them believed that it helped them acquire all the language skills, $29 \%$ said that it reduced the knowledge and $13 \%$ of them expressed that the subjects were limited with what the lecturer has taught. 
Table 4. Evaluating the success of the students in traditional education

\begin{tabular}{lllllll}
\hline \multirow{2}{*}{ Theme } & \multicolumn{2}{c}{ Traditional Education } \\
\cline { 2 - 7 } & \multicolumn{2}{c}{ Administrator } & \multicolumn{2}{c}{ Lecturer } & \multicolumn{2}{c}{ Student } \\
\cline { 2 - 7 } & $\mathbf{N}$ & $\mathbf{N}$ & $\mathbf{N}$ & $\mathbf{\%}$ & $\mathbf{N}$ & $\%$ \\
\hline Easily evaluate the students' performance & - & - & - & - & 14 & 58 \\
\hline Evaluate all skills & - & - & 4 & 33 & 6 & 25 \\
\hline Reduces knowledge & - & - & - & - & 7 & 29 \\
\hline Limited on what the lecturer has taught & - & - & - & - & 3 & 13 \\
\hline Students must study regularly & 4 & 50 & - & - & - & - \\
\hline Gives some ideas about the progress of the student & 2 & 25 & 4 & 33 & - & - \\
\hline Face-to-face interview & 2 & 25 & 3 & 25 & - & - \\
\hline Shape it according to your objective & - & - & 4 & 33 & - & - \\
\hline
\end{tabular}

Table 5. How traditional education develops the students' speaking skills and their accents in foreign language teaching

\begin{tabular}{lcccccc}
\hline \multirow{2}{*}{ Theme } & \multicolumn{5}{c}{ Traditional Education } \\
\cline { 2 - 7 } & \multicolumn{2}{c}{ Administrator } & \multicolumn{2}{c}{ Lecturer } & \multicolumn{2}{c}{ Student } \\
\cline { 2 - 7 } & $\mathbf{N}$ & $\mathbf{N}$ & $\mathbf{N}$ & $\mathbf{N}$ & $\%$ \\
\hline Sharing thoughts and ideas & - & - & 3 & 25 & 6 & 25 \\
\hline Encourage the students to communicate & - & - & 3 & 25 & 6 & 25 \\
\hline Peer correction & 2 & 25 & 3 & 25 & 6 & 25 \\
\hline Teaching phonology & - & - & 1 & 8 & 3 & 13 \\
\hline Using different methods & 6 & 75 & 12 & 17 & 3 & 13 \\
\hline
\end{tabular}

(A View (8)), "In our institution we are continuously assessing students therefore students are always active and aware that they must study regularly."

(L View (12)), "Our present syllabus which incorporates 5 pop quizzes, 2 main exams and 2 portfolios in particular are beneficial in that the writing one appears to be enriching the students' vocab, research Esummarising skills in addition to organising of information and presenting a speech on a chosen topic. The $2^{\text {nd }}$ (Edmodo) video portfolio is also useful as the students are encouraged to use technology from their everyday lives to film a short speech prepared by themselves."

(S View (28)), "Assignments and exams in traditional education are done mainly on the understanding of the students but some teachers give assignments and exams that the students do not really need making the students to stress while studying for the exams, or writing the assignments. Teachers should learn to give students what they need to know for the assignment and exams because as a student we have more courses to study and cannot continue doing less than good in our grades because we were studying unnecessary things."

Table 5. According to another research result, $75 \%$ of the administrators reported that they could improve the speaking skills and accents of the students in foreign language learning with traditional education by using different methods within the class and $25 \%$ of them stated that they could do this by peer correction. Of the lecturers and students, $25 \%$ reported that the speaking skills and accents of the students could be improved in foreign language learning with traditional education by sharing thoughts and ideas, $25 \%$ said this could be done by encouraging the students to communicate and $25 \%$ reported that this was possible through peer correction.

(A View (9)), "In Non-English-speaking countries traditional education can help the students' develop their speaking skills and accents, as the classroom is generally the only place where they can use the language. However, in English speaking countries the learners can improve their accents through distance learning by listening and watching online videos and using the language in the real world."

(L View (5)), "Traditional education develop the students' speaking skills by using different methods like reading aloud, presentations, picture description, storytelling, role plays, debates etc. Moreover, it gives students the chance to improve their accents with the help of lecturer. Therefore, traditional education is a good way of improving speaking skills."

(S View (13)), "There is interaction between the teacher and student. During teaching, in traditional education, the teacher can evaluate the level of learning of the students. Moreover, students can be easily corrected when they make mistakes in their speaking skills and their accents."

Table 6 shows the participants' views about modern technology in distance learning in foreign language teaching. $25 \%$ of the administrators believed that it could be accessed easily, anytime and anywhere, $25 \%$ thought that it helped students to prepare and deliver their projects and the other $25 \%$ stated that this kind of technology was not successful in foreign language. $13 \%$ of the administrators indicated that they could spare more time on four skills and $13 \%$ stated that they had the chance to record the lesson. We can see that both lecturers and students agreed on these views. 
Table 6. The participants' views about modern technology in distance learning in foreign language teaching

\begin{tabular}{|c|c|c|c|c|c|c|}
\hline \multirow{3}{*}{ Theme } & \multicolumn{6}{|c|}{ Distance Education } \\
\hline & \multicolumn{2}{|c|}{ Administrator } & \multicolumn{2}{|c|}{ Lecturer } & \multicolumn{2}{|c|}{ Student } \\
\hline & $\mathbf{N}$ & $\%$ & $\mathbf{N}$ & $\%$ & $\mathbf{N}$ & $\%$ \\
\hline Accessible easily, anytime, anywhere & 2 & 25 & 2 & 17 & 11 & 46 \\
\hline Spare more time on four skills & 1 & 13 & 2 & 17 & 12 & 50 \\
\hline Record the lesson & 1 & 13 & 4 & 33 & 1 & 4 \\
\hline Helps students to prepare and deliver their projects & 2 & 25 & 4 & 33 & - & - \\
\hline $\begin{array}{l}\text { This kind of technology is not successful in foreign } \\
\text { language }\end{array}$ & 2 & 25 & - & - & - & - \\
\hline
\end{tabular}

Table 7. The participants' views about modern technology in traditional education in foreign language teaching

\begin{tabular}{|c|c|c|c|c|c|c|}
\hline \multirow{3}{*}{ Theme } & \multicolumn{6}{|c|}{ Traditional Education } \\
\hline & \multicolumn{2}{|c|}{ Administrator } & \multicolumn{2}{|c|}{ Lecturer } & \multicolumn{2}{|c|}{ Student } \\
\hline & $\mathbf{N}$ & $\%$ & $\mathbf{N}$ & $\%$ & $\mathbf{N}$ & $\%$ \\
\hline Teachers can use different platforms & 1 & 13 & 4 & 33 & 3 & 13 \\
\hline Maximise learning time & 2 & 25 & 4 & 33 & 3 & 13 \\
\hline Improve students' confidence & 1 & 13 & 5 & 42 & 5 & 21 \\
\hline Improve teacher- student interaction & - & - & 2 & 17 & - & - \\
\hline Make the lesson become more interesting & 4 & 50 & 4 & 33 & 8 & 33 \\
\hline Record lessons & - & - & - & - & 1 & 4 \\
\hline Make learning easy and faster & - & - & - & - & 4 & 17 \\
\hline
\end{tabular}

Table 8. The advantages of using distance education in foreign language teaching

\begin{tabular}{|c|c|c|c|c|c|c|}
\hline \multirow{3}{*}{ Theme } & \multicolumn{6}{|c|}{ Distance Education } \\
\hline & \multicolumn{2}{|c|}{ Administrator } & \multicolumn{2}{|c|}{ Lecturer } & \multicolumn{2}{|c|}{ Student } \\
\hline & $\mathbf{N}$ & $\%$ & $\mathbf{N}$ & $\%$ & $\mathbf{N}$ & $\%$ \\
\hline Have the materials ready & 1 & 13 & 1 & 8 & 2 & 8 \\
\hline No time limit & 5 & 63 & 8 & 67 & 16 & 67 \\
\hline Allows learning everywhere & 2 & 25 & 3 & 25 & 6 & 25 \\
\hline
\end{tabular}

(A View (8)), "Modern technology in distance learning makes it easier for learners to prepare and deliver their projects and assignments. It gives them access to a variety of resources and data."

(L View (2)), "Modern technology has provided convenience in distance learning. It can be turned on/off at the student's convenience regardless of place or time, on a P.C, laptop or mobile phone. It can be stopped, paused and reminded to be listened to repeatedly if necessary."

(S View (13)), "In this modern technology students in distance learning have the opportunity to record the lessons then go back to it and learn little by little to get everything they couldn't get before. Moreover, it can be accessed easily anytime, anywhere."

Table 7 Administrators (50\%), lecturers (33\%) and students (33\%) expressed in their views on modern technology in traditional education for the foreign language teaching that it made the lesson become more interesting. Other administrators (13\%), lecturers (42\%) and students $(21 \%)$, on the other hand, argued that it provided an opportunity for the students to improve their confidence.

(A View (10)), "Smart boards makes the lessons become more interesting and attractive to students. Access to internet allows teaches to show videos, lectures and exercises related to their subjects."

(L View (16)), "Technology has changed the world of teaching as we know. It can't replace the teacher but it can improve teacher-student interaction, teachers can use different platforms like class flow to create new and existing lessons, it is also more inspiring in learning and also it can reduce assessment burden of teacher. Moreover, it maximises learning time such as students can watch lectures outside the classroom etc. As a result, using modern technology in traditional classroom can also improve students' confidence."

(S View (25)), "There are lots of ways to be successful in traditional education in foreign language education. If the teacher chooses the appropriate teaching method and specify clearly, I think she will make the lesson be more interesting."

Table 8 According to the results of another research, $63 \%$ of the administrators expressed that the advantage of distance education was that it lacked a time limit. $25 \%$ of the administrators mentioned that it allowed learning anywhere and $13 \%$ stated that it had the materials ready. Similarly, while $67 \%$ of both lecturers and students mentioned the lack of time limit, $25 \%$ reported that it allowed learning everywhere and $8 \%$ referred to the readiness of the materials. 
Table 9. The disadvantages of using distance education in foreign language teaching

\begin{tabular}{lcccccc}
\hline \multirow{2}{*}{ Theme } & \multicolumn{5}{c}{ Distance Education } \\
\cline { 2 - 7 } & \multicolumn{2}{c}{ Administrator } & \multicolumn{2}{c}{ Lecturer } & \multicolumn{2}{c}{ Student } \\
\cline { 2 - 7 } & $\mathbf{N}$ & $\boldsymbol{N}$ & $\mathbf{N}$ & $\mathbf{\%}$ & $\mathbf{N}$ & $\%$ \\
\hline Become disturbed easily & 4 & 50 & 2 & 17 & 1 & 4 \\
\hline No discussion & - & - & 3 & 25 & 2 & 8 \\
\hline Students cannot get immediate feedback & 2 & 25 & 2 & 17 & 1 & 4 \\
\hline No chance to improve accent & - & - & 2 & 17 & 2 & 8 \\
\hline Lack of social interaction & - & - & 2 & 17 & 15 & 63 \\
\hline Lack of discipline & - & - & 1 & 8 & - & - \\
\hline Temporary learning & 2 & 25 & - & - & 3 & 13 \\
\hline
\end{tabular}

(A View (4)), "An advantage of not having a time limit in distance education is the convenience it provides to the learner. The learner does not feel forced to be somewhere at a certain time. Thus, whenever he feels ready he can start learning. This makes the learner readier to learn."

(L View (17)), "Distance learning allows both the teacher and the students to fit their learning around their home life and work."

The main advantage of distance learning is that it allows you to fit your learning around your work and home life. For example, you can set when you want to study and when you want to do other things. You can also set your own pace of study too."

(S View (29)), "There are many advantages. For example, students get to choose a convenient time. Since there are too many materials in distance education."

Table 9 In reply to the final question of research, the administrators, lecturers and students have stated that the disadvantages of using distance education in foreign language teaching are as follows: $50 \%$ of the administrators stated that there was a chance of becoming disturbed easily and $25 \%$ mentioned that the students could not get immediate feedback. The other $25 \%$, on the other hand, expressed that it allowed temporary learning. While $25 \%$ of the lecturers believed that it was disadvantageous as there was no room for discussion, $17 \%$ mentioned the possibility of becoming disturbed easily, lack of immediate feedback for students, lack of the opportunity to improve the accent and lack of social interaction. The overwhelming $63 \%$ of the students, on the other hand, stated that the disadvantages were due to lack of social interaction. While $13 \%$ of them expressed that it enabled temporary learning, $8 \%$ mentioned the lack of room for discussion and the lack of the chance to improve the accent for the students. Finally, $4 \%$ of the students stated it was disadvantageous because of the possibility of becoming disturbed easily and the students' failing to get immediate feedback.

(A View (14)), "A disadvantage is, since there is no time limit, the learner might not do the work regularly and this causes the learning to be temporary."

(L View (31)), "There are disadvantages like lack of social interaction. Moreover, since there is no time limit there might be lack of discipline because you don't have a teacher there is no one to tell you the deadlines, there isn't anyone asking for assignments so you might not take it seriously."

(S View (40)), "As a disadvantage it can be said that students cannot get immediate feedback which is very important for them. Because when they have a question they cannot ask it to the teacher so, there is no discussion."

\section{DISCUSSION AND CONCLUSION}

Distance education continues to become widespread domestically however; it is at the minimum in foreign language education. It will be beneficial to divide research results into three parts. As per the initial research results, the majority of the administrators reported that distance education supported foreign language education in many ways. Administrators stated that distance learning provided flexibility in foreign language education and played an active role in learning and accessing. They added that foreign language contents provided through distance education were designed so as to facilitate self-study and develop studying abilities, accelerated learning, and that they could develop speaking skills and accents without a time limit. The administrators were thus of the view that distance education facilitated students' learning a foreign language. According to Ekmekçi (2014), foreign language education through distance learning generally met students' expectations.

According to secondary research results, most of the lecturers reported that they supported foreign language teaching by traditional education. According to lecturers, students had more chance to focus in the class which facilitated their learning, lecturers had opportunities to ask questions to students, had the chance to evaluate all language skills, they could have ideas about students' progress, had the opportunity for face-to-face interviews and could shape lectures according to the course of teaching in the class. They thus stated that distance learning did not facilitate learning. Ekmekçi (2014) evaluated that some language skills such as listening, writing and speaking were 
weak points of most students in foreign language learning through distance education. He is of the view that the presentation and integration of face-to-face language skills should be planned beforehand. When it comes to speaking and communication, oneself cannot learn a foreign language like learning the grammar and vocabulary. In order for a person learning a foreign language to take his/her speaking to an advanced level, another person or a group is needed. (Bozavli, 2017)

According to third research results, most of students preferred foreign language learning through distance education due to the lack of a time limit, its provision of flexibility in learning, its playing an active role in learning and accessing information, its facilitation of self-study and its facilitation of acquiring study skills. However, some of them preferred traditional education believing that it was more efficient, lecturers could evaluate their performances more easily, that students could be made to acquire all language skills and that it encouraged students to communicate. Since it does not have social clues about communicating individuals, it is thought to provide interpersonal non-individual communication (Kiesler vd, 1984). It is observed that most of the learners wished to continue face-to-face learning habits, did not wish to use the computer as a means of communication and thus did not have a positive stance (Bozkaya and Erdem Aydın, 2011).

Literature reviews indicate that online learning is not as efficient as in-class learning in foreign language education. While certain recent researches reveal the efficiency of student cooperation both in the class and online, they also indicate that since some of the students learnt more by themselves, they preferred to study independently. (Chih-cheng et al., 2011; Kikuchi, 2009; Liu et al., 2010; Vaughn et al., 2009; Yang, 2009).

Although technology integration is an integral tool for the classroom, some students still experience anxiety towards technology and learning a language, due to its many challenges (Kim, 2009; Sayadian and Lashkarian, 2010).

The most important reason of the rising interest towards distance education is that traditional education falls short. Fundamental innovations are necessary in the structure and a function of educational institutions and thus, it is required to plan the transformation in education policies (Arslan and Eraslan 2003).

Educational organizations should be structured in order to accomplish the goals set in line with the national education policy of a country. By these goals, precautions should be taken in order to train a work force in the required quality and quantity. Also, relevant organizations should effectively fulfil their part. They should be established and operate according to the principles of organization in order to be productive and successful. Organizations that comply with these principles become more successful in terms of harmony and competition with other systems and can achieve organizational aims in a planned manner.

Individualistic and societal relations have an important place in organization. In that sense, the physical activities such as production of goods and services and divisional separation of departments in the workplace are related with organization (Ergun and Polatoğlu, 1992) and involve the formation of the essential structure in order for a purpose which requires a common effort to be accomplished (Aydın, 1988). In organization, individuals are identified in order to fulfil a purpose and tools and equipment are provided for production. Methods and pathways leading to the purpose are determined and thus the process of organization emerges.

In this study, administrative functions were used to analyze distance education management. Since the layout of organizational units is dispersed in distance learning, the coordination, influence and evaluation diverge from institutions providing face-to-face education and this necessitates a virtual structuring. The study concluded that while managers and students were satisfied with foreign language learning through distance education, lectures were dissatisfied.

\section{REFERENCES}

Alkan, C. (2005). Ĕgitim Teknolojisi. Ankara: Anı Yayıncılık.

Arslan, M., \& Eraslan, L. (2003). Yeni Eğitim Paradigması ve Türk Eğitim Sisteminde Dönüşüm Gerekliliği, Milli Ĕ̈itim Dergisi, 160.

Aydın, M. (1988). Ĕ̆itim Yönetimi. Ankara: Hatiboğlu Yayınevi, Çă̆ Matbaası.

Bozavlı, E. (2017). Yeni Teknolojiler Işı̆̆ında Eğitim Aktörlerinin Yabancı Dil Öğretiminde Sanal Sınıf Algıları. Atatürk Üniversitesi Sosyal Bilimler Enstitüsü Dergisi, 21(1), 347-358.

Bozkaya, M., \& Erdem Aydın, İ. (2011). Uzaktan öğrenenlerin bilgisayar ortamlı iletişime yönelik algılamaları. Anadolu Üniversitesi journal of social sciences, 11(2), 179-192.

Chih-Cheng, L., Hsin-Jung, C., \& Hsien-Sheng, H. (2011). EFL students' perceptions of learning vocabulary in a computer-supported collaborative environment. Turkish Online Journal of Educational Technology, 10(2), 9199. 
Ekmekçi, E. (2014). Distance education in foreign language teaching: evaluations from the perspectives of freshman students. Procedia-Social and Behavioral Sciences, 176(2015), 390-397.

Ergün, T., \& Polatoğlu, A. (1992). Kamu Yönetimine Giriş. Ankara: T.O.D.A.İ.Yayınları. Sevinç Matbaası.

Früh, W. (2001). Inhaltsanalyse. Theorie und praxis. 5., Überarbeitete Auflage. Uvk: Konstanz.

Gürol, M., \& Turhan, M. (2004). Yönetim Fonksiyonları Bağlamında Uzaktan Eğitim Yönetimi. The Turkish Online Journal of Educational Technology-TOJET April 2005, 4(2).

İşman, A., \& Dabaj. F. (2005). Diffusion of distance education in North Cyprus. TOJDE, 6(4).

Kaya, Z. (2002). Uzaktan Ĕ̆itim. Ankara: Pegem A Yayınevi.

Kiesler, S., Siegel, J., \& McGuire, T. W. (1984). Social psychological aspects of computer-mediated communication. American Psychologist, 39(10), 1123-1134. Lea, M., \& Spears, R. (1991). Computer-mediatedcommunication.

Kikuchi, K. (2009). Listening to our learners' voices: what demotivates Japanese high school students? Language Teaching Research, 13(4), 453-471. doi:10.1177/1362168809341520

Kim, K.-J. (2009). Motivational challenges of adult learners in self-directed E-learning. Journal of Interactive Learning Research, 20(3), 317-335.

Liu, X., Liu, S., Lee, S.-H., \& Magjuka, R. J. (2010). Cultural differences in online learning: International student perceptions. Educational Technology E Society, 13(3), 177-188.

Punch, K. F. (2005). Introduction to Social Research-Quantitative \& Qualitative Approaches. London: Stage Pub.

Şahin, A. (2004). Yönetim kuramları ve motivasyon ilişkisi. Selçuk Üniversitesi Sosyal Bilimler Enstitüsü Dergisi, (11), 523-547.

Sayadian, S., \& Lashkarian, A. (2010). Investigating attitude and motivation of Iranian university learners toward English as a foreign language. Contemporary Issues in Education Research, 3(1), 137-147 (Ertuğrul, 1999).

Vaughn, S., Martinez, L. R., Linan-Thompson, S., Reutebuch, C. K., Carlson, C. D., \& Francis, D. J. (2009). Enhancing social studies vocabulary and comprehension for seventh-grade English language learners: Findings from two experimental studies. Journal of Research on Educational Effectiveness, 2(4), 297-324. doi:10.1080/19345740903167018

Weber, M. M. (2002). Measuring Supply Chain Agility in the Virtual Organizations. International Journal of Physical Distribution and Logistics, 32(7), 577-590.

Williams, P. (2000). Making Informed Decisions about Staffing and Training: Roles and Competencies for Distance Education Programs in Higher Education. Distance Learning Administration Conference, 2001. Retrieved from http://www.westga.edu/ distance/ojdla/winter64/black64.htm

\section{http://www.ejmste.com}

